\title{
TRPM5 mediates acidic extracellular pH signaling and TRPM5 inhibition reduces spontaneous metastasis in mouse B16-BL6 melanoma cells
}

\author{
Toyonobu Maeda ${ }^{1, *}$, Atsuko Suzuki, ${ }^{1,}$, Kaori Koga ${ }^{2}$, Chihiro Miyamoto ${ }^{3}$, Yojiro \\ Maehata $^{3}$, Shigeyuki Ozawa ${ }^{4}$, Ryu-Ichiro Hata ${ }^{4,5}$, Yoji Nagashima ${ }^{6}$, Kazuki \\ Nabeshima' ${ }^{2}$, Kaoru Miyazaki and Yasumasa Kato ${ }^{1}$ \\ ${ }^{1}$ Department of Oral Function and Molecular Biology, Ohu University School of Dentistry, Koriyama 963-8611, Japan \\ ${ }^{2}$ Department of Pathology, Fukuoka University School of Medicine and Hospital, Fukuoka 814-0180, Japan \\ ${ }^{3}$ Department of Oral Science, Kanagawa Dental University Graduate School of Dentistry, Yokosuka 238-8580, Japan \\ ${ }^{4}$ Department of Dentomaxillofacial Diagnosis and Treatment, Kanagawa Dental University Graduate School of Dentistry, \\ Yokosuka 238-8580, Japan \\ ${ }^{5}$ Oral Health Science Research Center, Kanagawa Dental University Graduate School of Dentistry, Yokosuka 238-8580, Japan \\ ${ }^{6}$ Department of Surgical Pathology, Tokyo Women's Medical University Hospital, Tokyo 162-8666, Japan \\ ${ }^{7}$ Molecular Pathology and Genetics Division, Kanagawa Cancer Center Research Institute, Yokohama 241-8515, Japan \\ *These authors contributed equally to this work \\ Correspondence to: Yasumasa Kato, email: yasumasa-kato@umin.ac.jp
}

Keywords: MMP-9, acidic extracellular pH, TRPM5, melanoma, metastasis

Received: April 28, $2017 \quad$ Accepted: August 27, $2017 \quad$ Published: September 11, 2017

Copyright: Maeda et al. This is an open-access article distributed under the terms of the Creative Commons Attribution License 3.0 (CC BY 3.0 ), which permits unrestricted use, distribution, and reproduction in any medium, provided the original author and source are credited.

\section{ABSTRACT}

Extracellular acidity is a hallmark of solid tumors and is associated with metastasis in the tumor microenvironment. Acidic extracellular $\mathbf{p H}\left(\mathrm{pH}_{\mathrm{e}}\right)$ has been found to increase intracellular $\mathrm{Ca}^{2+}$ and matrix metalloproteinase-9 (MMP-9) expression by activating NF-KB in the mouse B16 melanoma model. The present study assessed whether TRPM5, an intracellular $\mathrm{Ca}^{2+}$-dependent monovalent cation channel, is associated with acidic $\mathrm{pH}_{e}$ signaling and induction of MMP-9 expression in this mouse melanoma model. Treatment of B16 cells with Trpm5 siRNA reduced acidic $\mathrm{pH}_{\mathrm{e}}$-induced MMP-9 expression. Enforced expression of Trpm5 increased the rate of acidic $\mathrm{pH}_{\mathrm{e}}$-induced MMP-9 expression, as well as increasing experimental lung metastasis. This genetic manipulation did not alter the $\mathrm{pH}_{e}$ critical for MMP-9 induction but simply amplified the percentage of inducible MMP-9 at each $\mathbf{p H}_{\mathrm{e}^{*}}$ Treatment of tumor bearing mice with triphenylphosphine oxide (TPPO), an inhibitor of TRPM5, significantly reduced spontaneous lung metastasis. In silico analysis of clinical samples showed that high TRPM5 mRNA expression correlated with poor overall survival rate in patients with melanoma and gastric cancer but not in patients with cancers of the ovary, lung, breast, and rectum. These results showed that TRPM5 amplifies acidic $\mathrm{pH}_{e}$ signaling and may be a promising target for preventing metastasis of some types of tumor.

\section{INTRODUCTION}

Extracellular acidity, resulting from an increase in lactate concentration, a process known as "aerobic glycolysis" or "Warburg effect", is a hallmark of solid tumors [1]. We have found that acidic extracellular $\mathrm{pH}\left(\mathrm{pH}_{e}\right)$ induces the production of matrix metalloproteinase-9 (MMP-9), the activity of which correlated with the metastatic ability of mouse B16 melanoma variants $[2,3]$. In the intracellular signaling 
pathway for acidic $\mathrm{pH}_{e}$-induced MMP-9 expression, phospholipase D1 (PLD1) - mitogen activated protein (MAP) kinases (extracellular signal-regulated kinase $1 / 2$ and $\mathrm{p} 38)$ - nuclear factor $-\kappa \mathrm{B}(\mathrm{NF}-\kappa \mathrm{B})$ pathway plays an important role [4]. Acidic sphingomyelinase is also associated with NF- $\kappa$ B activation [5]. Importantly, acidic $\mathrm{pH}_{e}$-induced PLD1 activation is due to both the up-regulation of $\mathrm{Ca}^{2+}$ influx through voltage-gated $\mathrm{Ca}^{2+}$ channels and the activation of RhoA $[5,6]$. Moreover, in some models, acidic $\mathrm{pH}_{e}$ has been reported to alter cell shape, from epithelial to fibroblastic [2, 7-9].

Melastatin (melastatin 1/TRPM1) is the first molecule of the transient receptor potential melastatin (TRPM) family to be identified. Although the level of expression of TRPM1 is inversely correlated with metastasis of human melanoma [10]. A recent study, however, showed that TRPM1 did not predict overall survival in patients with clinical AJCC stages I and II melanoma [11]. TRPM belongs to a non-selective cation channel family with six transmembrane structures. Although eight genes have been identified, TRPM4 and TRPM5 are the only $\mathrm{Ca}^{2+}$-activated nonselective monovalent cation channels, which carry $\mathrm{Na}^{+}, \mathrm{K}^{+}$, and $\mathrm{Cs}^{+}$ ions, and may be important for membrane depolarization that triggers neuronal responses [12, 13]. TRPM5 has been reported to be associated with sweet and umami, but not sour, taste signaling in taste buds in a heat-dependent manner $[14,15]$. Interestingly, TRPM5 activity is affected by acidic $\mathrm{pH}_{e}$, resulting in a rapid reversible block in current $\left(\mathrm{IC}_{50} \mathrm{pH}=6.2\right)$ and a slower irreversible inactivation of current [13].

Tumor invasion and metastasis are regulated by membrane potential through potassium and sodium channels and exchangers, so that experimental inhibition of these channels successfully reduces tumor metastasis. For example, inhibition of the potassium channels, KCNK9 [16], Kv10.1 [17], hEag1 [18], and HERG1 [19] inhibited tumor metastasis, as did inhibition of the sodium channels, $\mathrm{Na}(\mathrm{v} 1.4)$ [20] and $\mathrm{Na}(\mathrm{v}) 1.5$ [21] and the sodium proton exchanger, NHE1 [22, 23].

Although intracellular $\mathrm{Ca}^{2+}$, which is apparently increased by acidic $\mathrm{pH}_{e}$ [5], indirectly activates PLD1 through protein kinase $\mathrm{C} \alpha(\mathrm{PKC} \alpha)$, a conventional PKC isotype dependent on $\mathrm{Ca}^{2+}$ and diacylglycerol [24], the PKC activator phorbol-12-myristate-13-acetate (TPA) could not mimic acidic $\mathrm{pH}_{e}$-induced MMP-9 expression by mouse B16 cells at neutral $\mathrm{pH}_{e}[2]$, suggesting that elevation of intracellular $\mathrm{Ca}^{2+}$ affects other targets. Our preliminary experiments using $\mathrm{K}^{+}$- and $\mathrm{Na}^{+}$-sensitive fluorescent dyes, such as the $\mathrm{K}^{+}$-binding dye benzofuran isophthalate (PBFI-AM) and the $\mathrm{Na}^{+}$-binding dye benzofuran isophthalate (SBFI-AM), showed that PBFIAM, but not SBFI-AM, dose-dependently inhibited acidic $\mathrm{pH}_{e}$-induced MMP-9 production. These findings prompted a determination as to whether TRPM5, a transient $\mathrm{Ca}^{2+}$ activated cation channel, is involved in the acidic $\mathrm{pH}_{e}$ signaling that induces MMP-9 expression in melanoma.

\section{RESULTS}

\section{Trpm 5 mRNA is highly expressed in the metastatic B16 melanoma variant BL6}

Levels of Trpm 5 mRNAs were compared in F1 (low metastatic), F10 (highly metastatic experimentally but not spontaneously) and BL6 (highly metastatic in both models) $[10,25,26]$. In addition, levels of Trpm1 mRNA, a prototype of TRPM, were compared, as these levels were found to inversely correlate with metastatic ability [10, 25, 26]. Levels of Trpm 1 mRNA expression among B16 melanoma variants were in the descending order BL6, F1, and F10, but were not affected by acidic $\mathrm{pH}_{e}$ (Figure 1A). In contrast, Trpm 5 mRNA expression was detected in all three variants, being relatively high in BL6 cells but low in F1 and F10 cells. In addition, Trpm 5 mRNA expression was significantly induced in all variants by acidic $\mathrm{pH}_{e}$. Especially, the induction in BL6 cells was extremely stimulated by acidic $\mathrm{pH}_{e}$ (Figure 1B). All variant cell lines tested were positive for mRNAs encoding other subtypes of Trpm, except for Trpm4b, Trpm6, and Trpm8. Although levels of Trpm $3 a$ and Trpm $4 a$ mRNAs were higher at acidic than at neutral $\mathrm{pH}_{e}$, these levels did not correlate with the metastatic ability of B16 melanoma variants (data not shown).

\section{TRPM5 reduction inhibits acidic $\mathrm{pH}_{e}$-induced MMP-9 expression}

To determine the association between TRPM5 and acidic $\mathrm{pH}_{e}$ signaling, we tested the effect of siRNA specific for Trpm5 mRNA on MMP-9 production at acidic $\mathrm{pH}_{e}$. The siRNA for Trpm5 markedly reduced $\mathrm{pH}_{e}$-induced MMP-9 expression (Figure 2A-2C and Supplementary Figure 1), suggesting that TRPM5 is involved in acidic $\mathrm{pH}_{e}$ signaling that induces MMP-9 production. In addition, Trpm5 siRNA inhibited acidic $\mathrm{pH}_{e}$-induced cellular elongation, to a fibroblastic shape characteristic of changes associated with epithelial mesenchymal transition (EMT) (Figure 2D and Supplementary Figure 2).

\section{Enforced expression of TRPM5 amplifies acidic $\mathbf{p H}_{e}$ signaling}

To determine whether TRPM5 can sensitize cells to acidic $\mathrm{pH}_{e}$, thereby inducing MMP-9 expression, a Trpm5 gene expression vector was introduced into BL6 cells. Cell clones expressing high levels of TRPM5 protein were tested for the ability of acidic $\mathrm{pH}_{e}$ to induce MMP-9 (Figure 3A). As expected, cells expressing high TRPM5 levels showed an increase in acidic $\mathrm{pH}_{e}$-induced MMP-9 expression, but there was no effect on cell proliferation (Figure 3B-3D). Because the highest $\mathrm{pH}$ to induce MMP-9 production by both mock control and TRPM5overexpressing cells was 7.2, these results suggested 
that the effect of $\mathrm{pH}$ on MMP-9 production was due to amplification of the acidic $\mathrm{pH}_{e}$ signal rather than to an increase in critical $\mathrm{pH}_{e}$. As reported previously [6], acidic $\mathrm{pH}_{e}$ increased stress fiber formation, an effect enhanced by the forced expression of the Trpm 5 gene (Figure 3E and Supplementary Figure 3). Because TRPM5 activity is thermo-dependent [14], we also tested the effect of incubation temperature on acidic $\mathrm{pH}_{e}$-induced MMP-9 production. The acidic $\mathrm{pH}_{e}$ induction of MMP-9 at $37^{\circ} \mathrm{C}$ was obviously reduced when cells were incubated at $30^{\circ} \mathrm{C}$ or $25^{\circ} \mathrm{C}$ while $\operatorname{Trpm} 5$ and $M M P 2$ mRNA expression were not inhibited between neutral and acidic $\mathrm{pH}_{e}$ at each temperature, showing that channel activity of TRPM5 required to transduce acidic $\mathrm{pH}_{e}$ signaling (Supplementary Figure 4).

\section{Enforced expression of Trpm 5 induces experimental lung metastasis}

Injection of Trpm5 transfectants into the tail veins of mice doubled the number of metastasized foci in the lungs observed following injection of mock transfectants (Figure 4). This result clearly indicated that TRPM5 plays an important role in the pulmonary metastasis of melanoma cells.

\section{Triphenylphosphine oxide (TPPO) treatment reduces acidic $\mathrm{pH}_{e}$-induced MMP-9 production and spontaneous metastasis of melanoma}

The ability of chemotherapy targeting TRPM5 to prevent lung metastasis was assessed by evaluating the effect of TTPO, a pharmacologic inhibitor of TRPM5 activity [27], on acidic $\mathrm{pH}_{e}$-induced MMP-9 expression. As expected, TPPO dose-dependently inhibited acidic $\mathrm{pH}_{e}$-induced MMP-9 production ( $\mathrm{IC}_{50}: 41 \mathrm{mM}$ after $24 \mathrm{~h}$ ) (Figure 5A and 5B), but did not reduce cell viability. Rather, high concentrations of TPPO slightly promoted cell growth (Figure 5C). Although acidic $\mathrm{pH}_{e}$ induced

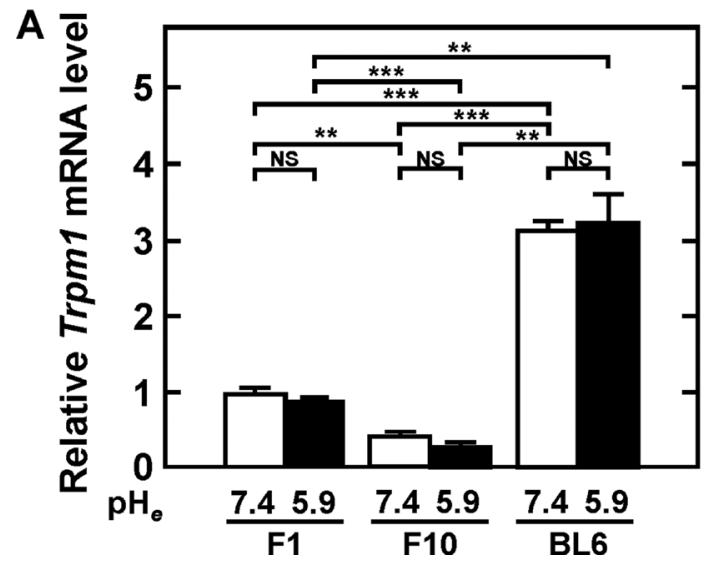

Trpm5 gene expression, TPPO did not reduce the level of Trpm 5 mRNA (Figure 5D). However, it inhibited acidic $\mathrm{pH}_{e}$-induced NF- $\mathrm{\kappa B}$ activity and expression of EMTrelated genes, such as $M m p 9$, $\operatorname{Vim}$ (vimentin), and $C d h 2$ (N-cadherin) (Figure 6). These results suggested that EMT-related gene expression was up-regulated by acidic $\mathrm{pH}$ through TRPM5 and that pharmacological inhibition of TRPM5 activity was effective in preventing acidic $\mathrm{pH}_{e}$-induced EMT. Because acidic $\mathrm{pH}_{e}$ induced Trpm5 mRNA expression and this induction was not inhibited by TPPO, the mechanism involved in the up-regulation of Trpm 5 mRNA expression differs from that involved in the induction of $M m p 9$ and other genes. Finally, TRPM5 was targeted in melanoma bearing mice by treatment with TPPO. B16-BL6 cells were inoculated into the left footpads of these mice, followed by subcutaneous injection of TPPO every other day. Three weeks after cell injection, and while continuing TPPO administration, the limb containing the primary tumor was amputated. Four weeks later, the mice were sacrificed and the numbers of metastatic foci were counted. TPPO treatment clearly prevented pulmonary metastasis of B16-BL6 cells (Figure 7A), but had no effect on the primary tumor mass or on body weight (Figure 7B-7D). Because TRPM5 has been reported associated with insulin secretion [28], casual blood glucose (CBG) levels were measured after TPPO treatment. TPPO did not significantly affect blood glucose concentrations in these mice (Figure 7E).

\section{Expression of TRPM5 in tumor patients}

We further checked whether TRPM5 expression predicts clinical outcome for human melanoma patients. Immunohistochemical staining of clinical specimens showed that all primary (Figure 8A) and secondary (Figure 8B) lesions were positive for TRPM5 protein, with no significant difference in TRPM5 protein levels between primary and metastatic sites (Table 1). In silico analysis of TRPM5 mRNA levels in clinical samples

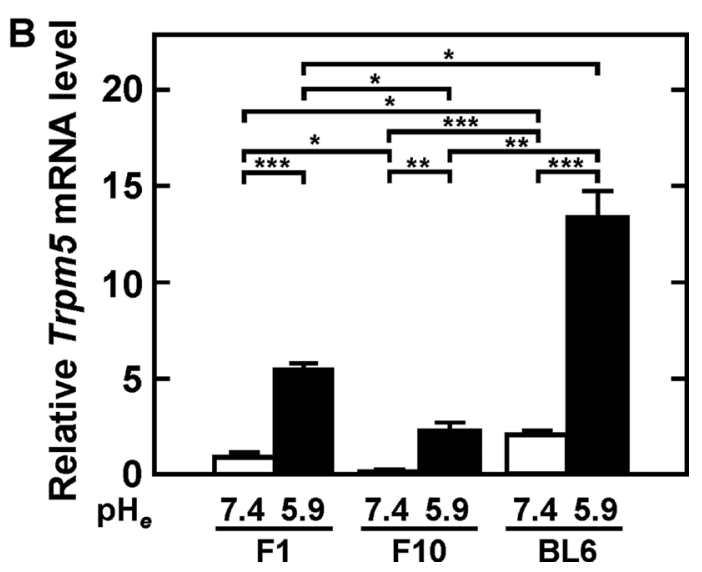

Figure 1: Expression of Trpm1 (A) and Trpm5 (B) mRNAs by confluent cultures incubated with serum-free medium at the indicated $\mathrm{pH}$ for $24 \mathrm{~h}$. Total RNA was extracted and reverse transcribed for RT-qPCR. Data were expressed, relative to the level of $\mathrm{F} 1 \mathrm{cells}$ at $\mathrm{pH} \mathrm{H}_{e} 7.4$, as mean \pm SE in triplicate assay. $* P<0.05$, $* * P<0.01$, $* * * P<0.001$. NS, not significant. 
Table 1: Immunocytochemistry of TRPM5 expression in melanoma patients

\begin{tabular}{ccc}
\hline Site & \multicolumn{2}{c}{ Intensity } \\
\cline { 2 - 3 } & ++ & +++ \\
\hline Primary $^{\mathrm{a})}$ & $6(40 \%)$ & $(60 \%)$ \\
Secondary $^{\mathrm{b})}$ & $9(47 \%)$ & $10(53 \%)$ \\
\hline
\end{tabular}

a) 13 in skin, 1 in eyeball, and 1 in nasal cavity

b) 8 in lymph node, 6 in skin, 2 in brain, 1 in soft tissue, 1 in lung, and 1 in liver.

$P=0.468$
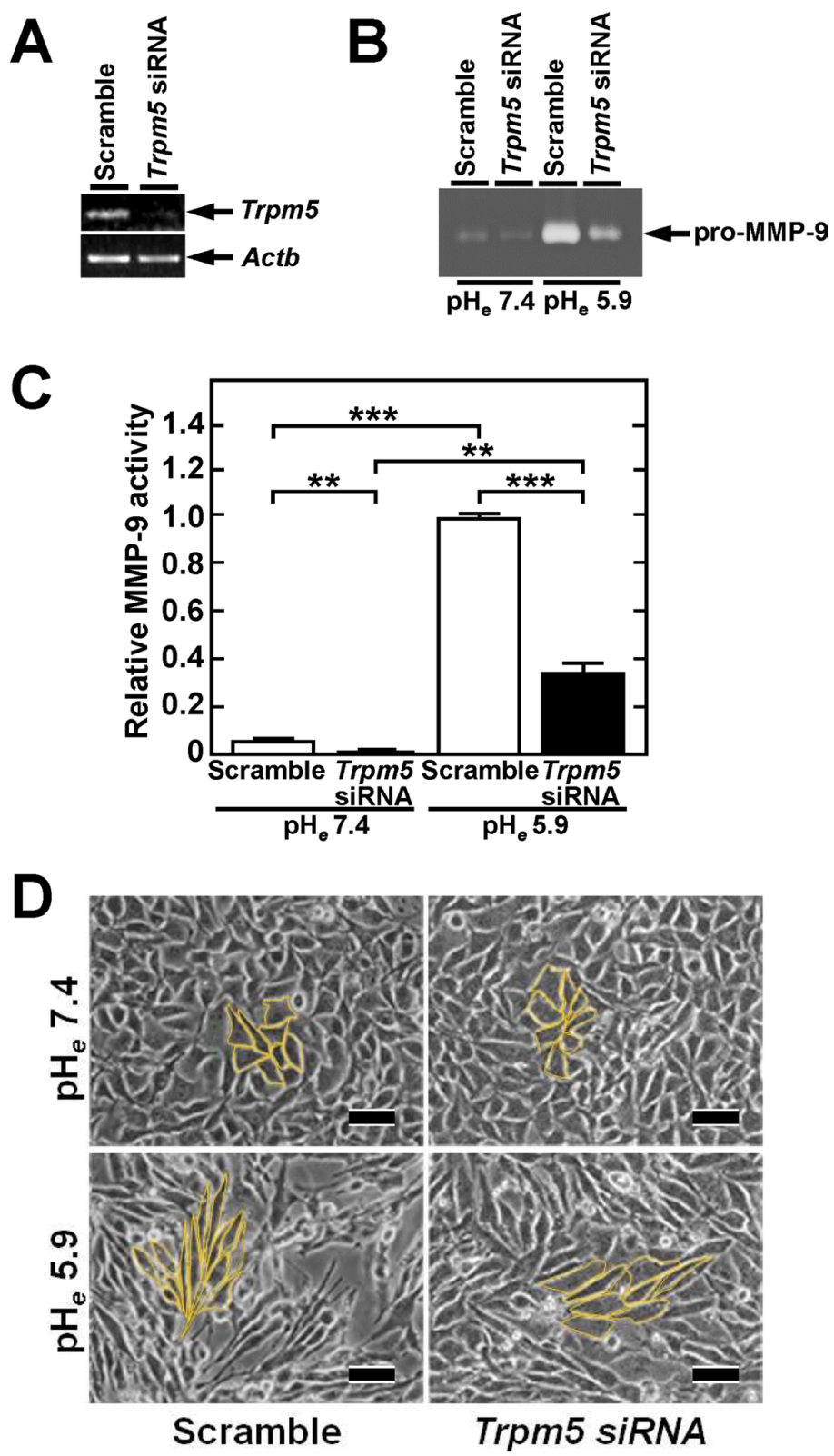

Figure 2: Introduction of Trpm5 siRNA reduces acidic $\mathrm{pH}_{e}$-induced MMP-9 production and alters morphology to fibroblastic. (A) Reduction of Trpm 5 mRNA by transfection of Trpm 5 siRNA. PCR product was separated on agarose gel and stained with ethidium bromide. Reduction rate by siRNA was quantified by qPCR (see Supplementary Figure 1). (B) Inhibition of acidic $\mathrm{pH}_{e}^{-}$ induced MMP-9 production by transfection of Trpm 5 siRNA. Following transfection, the cells were incubated in serum-free medium at neutral and acidic pH. The MMP-9 concentration of conditioned medium was analyzed by gelatin zymography. (C) Densitometric analysis of MMP-9 activity on zymogram in $\mathrm{B}(n=3)$. Data were expressed relative to maximum induction at $\mathrm{pH}_{e}$ 5.9. (D) Acidic $\mathrm{pH}_{e}$ induced fibroblastic shape, but this change was inhibited by introduction of $\operatorname{Trpm} 5$ siRNA. Representative results are shown. Bar, $50 \mu \mathrm{m}$. Cell shapes are highlighted in yellow line and their quantification is shown in Supplementary Figure 2. 
from cancer patients were correlated with overall survival using an open database. High TRPM5 expression in melanoma patients was associated with shorter survival time (Figure 9A). Interestingly, this correlation was much clearer in gastric cancer patients (Figure 9B), but was not observed in patients with ovarian (Figure 9C), lung (Figure 9D), breast (Figure 9E) and rectal (Figure 9F) cancer. These findings suggested that TRPM5 expression is closely associated with prognosis in patients with melanoma and gastric cancer, but not in patients with other tumor types.

\section{DISCUSSION}

We previously reported that acidic $\mathrm{pH}_{e}$ induces MMP9 production in mouse B16 melanoma cells and cell invasion through type IV collagen sheets, as well as activating intracellular signaling pathways [4]. These pathways involve $\mathrm{Ca}^{2+}$-triggered PLD activation followed by activation of MAP kinases (extracellular signal-regulated kinase $1 / 2$ and p38) and NF-кB [4]. Acidic sphingomyelinase is also involved in acidic $\mathrm{pH}_{e}$ induction of NF- $\kappa \mathrm{B}$ [5]. PLD1, but not PLD2, was shown to contribute to acidic $\mathrm{pH}_{e}$-induced MMP-9 signaling, with RhoA activating PLD1 [6]. The present study further explored this acidic $\mathrm{pH}_{e}$ sensing system, finding that TRPM5 was involved in acidic $\mathrm{pH}_{e}$-induced MMP9 expression. The TRPM5 inhibitor TPPO significantly inhibited spontaneous metastasis to the lungs. In addition, in silico analysis showed a significant correlation between high levels of TRPM5 expression and shorter overall survival in patients with melanoma and gastric cancer, but not in patients with cancers of the lung, breast, and rectum. These findings suggest that TRPM5 may be a potential therapeutic target, as its inhibition may prevent metastasis and prolong overall survival of patients with melanoma and gastric cancer. This study also found that Trpm 5 mRNA expression was induced by acidic $\mathrm{pH}_{e}$ but that this induction was not inhibited by TPPO treatment.

In mice, most Trpm 5 mRNA is present in organs such as the taste buds, stomach, and small intestine [29]. The present study showed that overall survival of gastric cancer patients was significantly shorter in patients with high than low levels of TRPM5. Chronic gastritis and
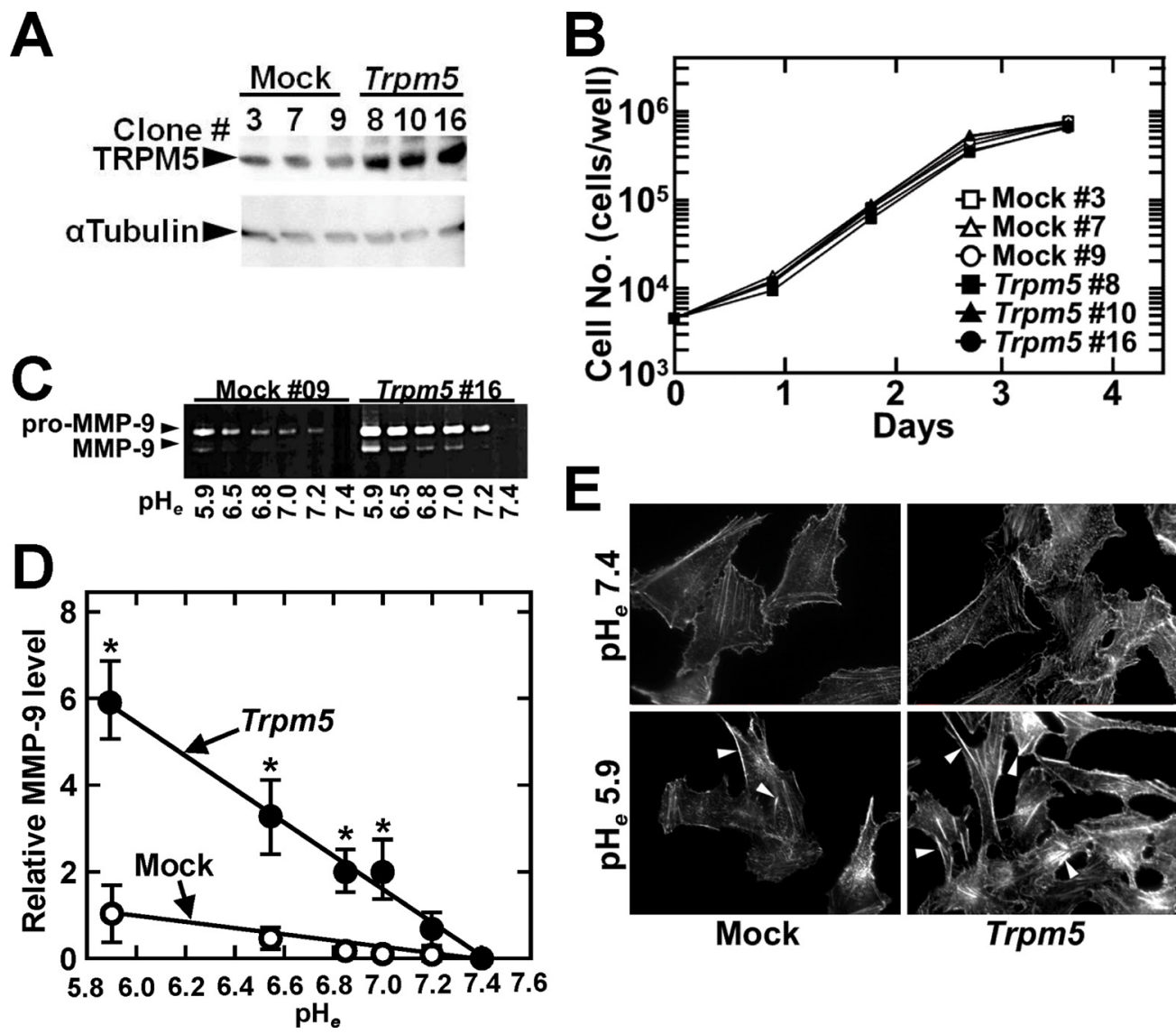

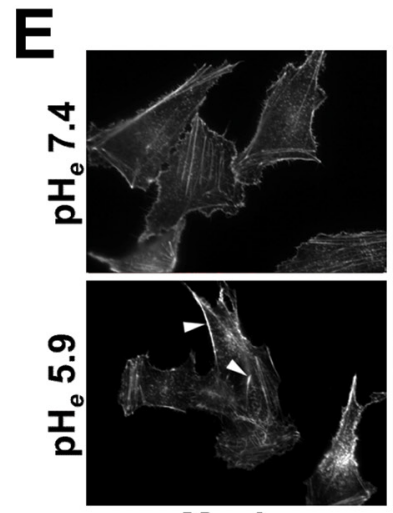

Mock

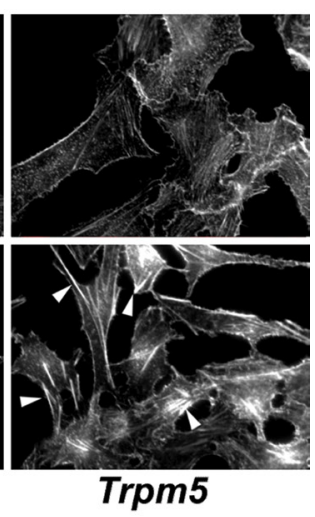

Figure 3: Constitutive expression of Trpm 5 mRNA does not affect cell growth but increases the induction of MMP-9 and actin reorganization by acidic $\mathbf{p H}_{e}$. (A) Western blotting of representative clones of Trpm5-expressing vector transfected cells. (B) Growth curves of the representative clones $(n=3)$. (C) Zymographic analysis of acidic $\mathrm{pH}_{e}$-induced MMP-9 secretion from clone \#9 of mock and \#16 of Trpm 5 transfectants. This panel shows application of 1/4 samples to see differences in expression. (D) Densitometric analysis of the results consisting of three-clone each transfectants: Mock (\# 3, \#7, and \#9 in (C)) and Trpm5 (\#8, \#10, and \#16 in (C)). (E) Rhodamine-phalloidin staining. Arrowheads show actin stress fibers, whose quantification is shown in Supplementary Figure 3. 
A

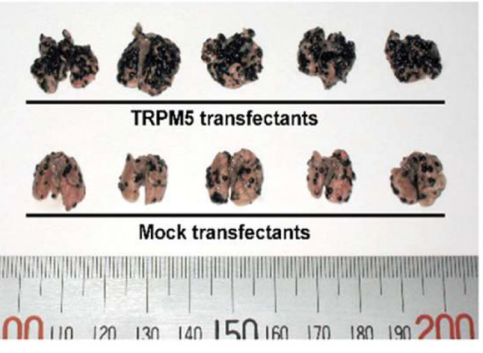

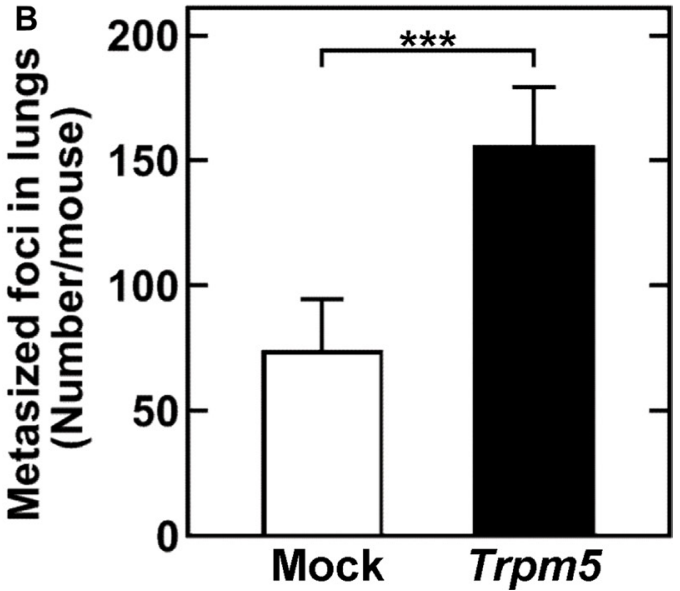

Figure 4: Constitutive Trpm 5 mRNA expression increases experimental pulmonary metastasis through tail vein injection of B16-BL6 cells. Representative clones of cells transfected with empty vector (control) and Trpm5-expressing vector (Trpm5) were grown individually, pooled and injected into tail veins of mice. (A) Photograph of a lung 3 weeks after injection. (B) Metastasized foci at the lung surface. Data are represented as mean $\pm \operatorname{SE}(n=15) .{ }^{* * *} P<0.01$.
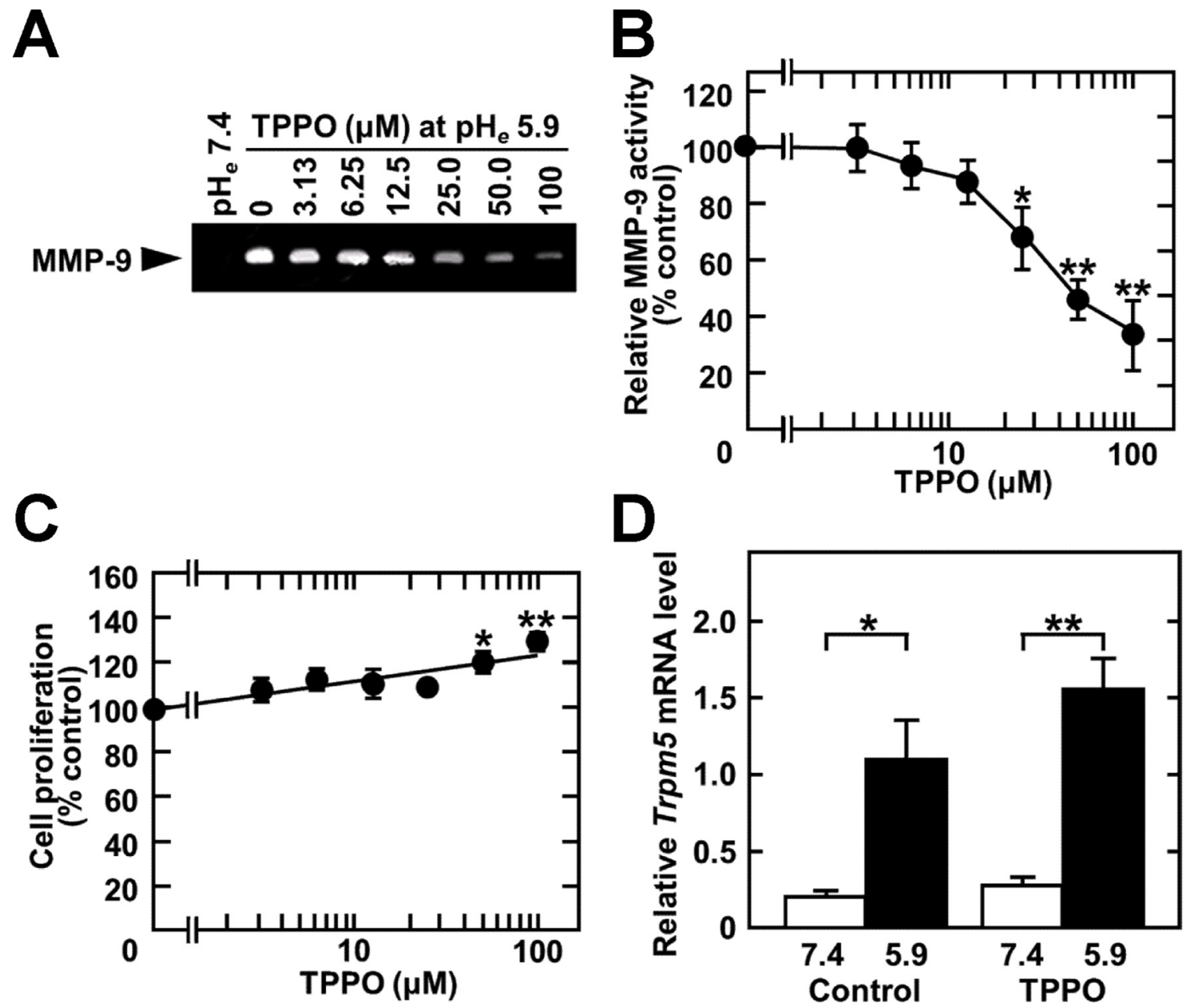

Figure 5: TPPO treatment inhibits acidic $\mathbf{~} \mathrm{PH}_{e}$-induced MMP-9 production. Cells were treated with the indicated concentration of TPPO in serum-free medium for $24 \mathrm{~h}$. (A) Conditioned media were concentrated and analyzed by zymography. (B) Densitometric analysis of the results in (A). (C) Cells were cultured with the indicated concentrations of TPPO in the presence of 10\% FBS for 2 days, and cell survival was measured by the CCK8 assay. (D) Cells were pre-treated for $1 \mathrm{~h}$ and treated for a further $24 \mathrm{~h}$ with $50 \mathrm{mM}$ of TPPO in the absence of serum. Total RNA was extracted, reverse-transcribed, and amplified by qPCR. Data are represented as mean $\pm \operatorname{SE}(n=3)$. $* P<0.05, * * P<0.01$. 
peptic ulcers are closely associated with the development of gastric cancer [30], as tumor cells seem to selectively grow in these environments. Taken together, these findings indicate that TRPM5 may be associated with cell adaptation to acidic $\mathrm{pH}_{e}$.

Molecular targeting chemotherapy agents inhibit the growth of tumor cells and/or induce their apoptosis. These agents include imatinib and ponatinib, which inhibit BCR-ABL tyrosine-kinase and are used to treat chronic myelogenous leukemia (CML) and gastrointestinal stromal tumors (GISTs) [31, 32]; gefitinib, erlotinib, and afatinib, which inhibit epidermal growth factor receptor (EGFR) tyrosine kinase and are used to treat lung cancer [33]; and trastuzumab, an anti-HER2 antibody, which is used to treat breast cancer [34]. Inhibitory agents targeting the Warburg effect include echinomycin (NSC-13502), which targets HIF1 [35]; HOE 642 (Caripride) [23, 36], zoniporide (CP-597,396) [37], EMD 84021, EMD 94309, and EMD 96785 (eniporide) [38], which target $\mathrm{Na}^{+} / \mathrm{H}^{+}$-exchanger 1 (NHE1); and sulfonamide (sulfamates), coumarins, and girentuximab (monoclonal antibody against G250 antigen), which target CAIX [39]. These drugs inhibit the generation of acidic $\mathrm{pH}_{e}$ microenvironments. Because acidic $\mathrm{pH}_{e}$ induces MMP-9 expression and cell migration into type IV collagen sheets [2], we hypothesized that acidic $\mathrm{pH}_{e}$ is not only a consequence of the Warburg effect but a trigger of the metastatic phenotype. Our hypothesis has been confirmed by evidence, from not only our group but also other groups, showing that acidic $\mathrm{pH}_{e}$ induces the disruption of extracellular matrices, as well as tumor
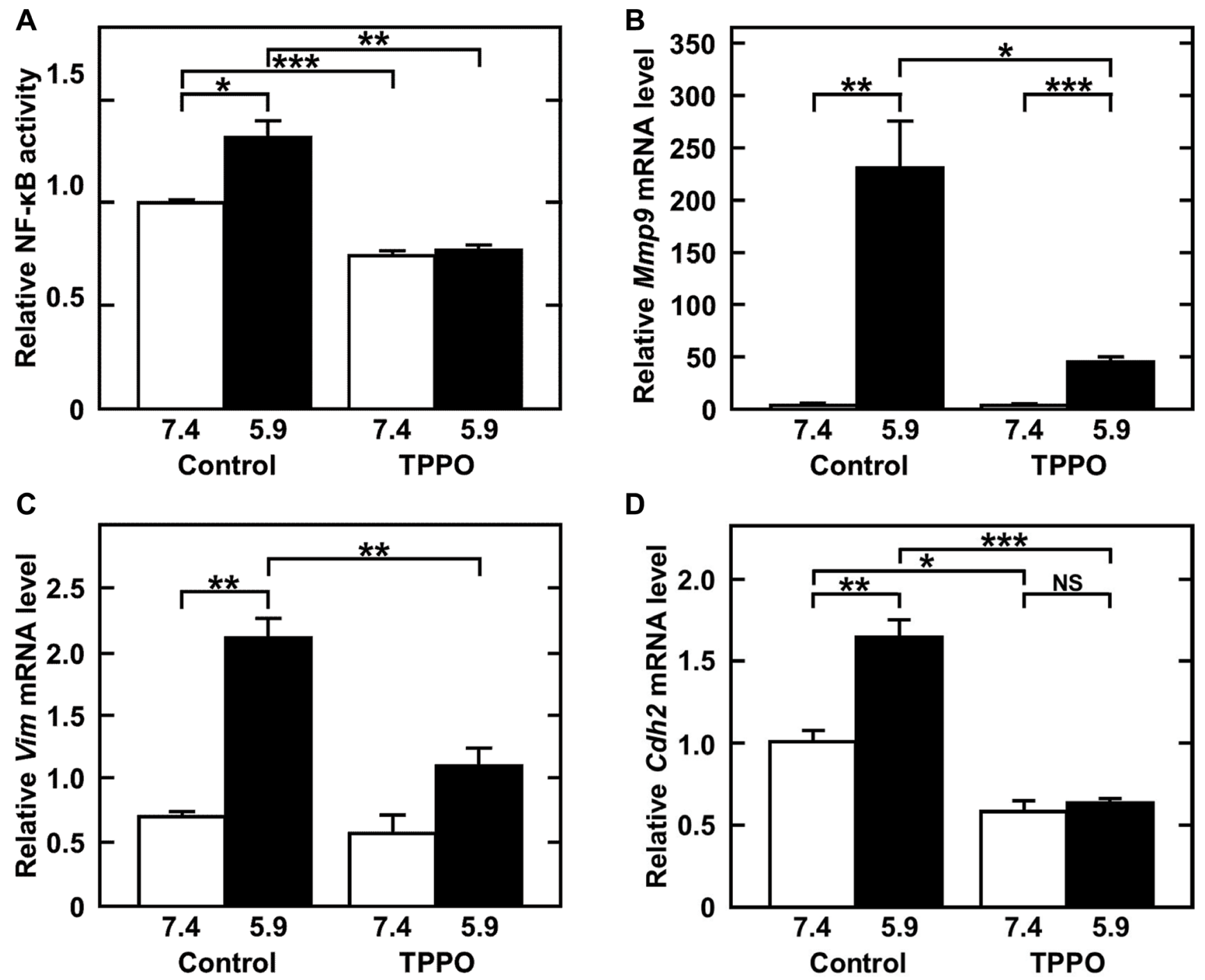

Figure 6: TPPO treatment inhibits acidic- $\mathrm{pH}_{e}$-induced NF- $\mathrm{KB}$ activity (A) and $M m p 9$ (B), Vim (vimentin) (C), and Cdh2 (N-cadherin) (D) mRNA levels. (A) Cells were transfected with NF- $\kappa$ B-driven luciferase vector, pre-treated with $50 \mathrm{mM}$ of TPPO in serum-free medium at neutral $\mathrm{pH}_{e}$ for $1 \mathrm{~h}$, and then treated with $50 \mathrm{mM}$ of TPPO in serum-free medium at acidic $\mathrm{pH}_{e}$ for $24 \mathrm{~h}$. Cell lysates were collected and NF- $\kappa$ B-driven luciferase activity measured. (B-D) Cells were pre-treated for $1 \mathrm{~h}$ and treated for a further $24 \mathrm{~h}$ with $50 \mathrm{mM}$ of TPPO in the absence of serum. Total RNA was extracted, reverse-transcribed, and amplified by qPCR. Data are represented as mean $\pm \mathrm{SE}(n=3)$. $* P<$ $0.05, * * P<0.01, * * * P<0.005$. 
invasion and metastasis [40-48]. Agents that target the acidic $\mathrm{pH}_{e}$ sensing machinery, such as ASIC1a $[49,50]$ and TRPV1 (vanilloid receptor) [51], can prevent tumor growth. TRPV1, which can be activated by chemical stimuli such as capsaicin, $\mathrm{H}^{+}$, and heat, is a pain receptor [52-54]. Administration of capsazepine, an antagonist for TRPV1, has been found to prevent cutaneous vasodilation [55], suggesting that capsazepine may be a promising candidate for prevention of tumor growth, although its ability to prevent metastasis remains unclear. On the other hand, we showed that constitutive expression of TRPM5 is apparently uninvolved in tumor growth in vivo. Moreover, TPPO treatment did not reduce tumor growth in vivo; rather, high concentrations of TPPO slightly enhanced tumor growth in vitro, perhaps due to a side effect of
TPPO. Clinically, therefore, TRPM5 inhibitors may be administered together with cytostatic and/or cytotoxic agents. Because TRPM7 contributes to the invasiveness of glioblastoma in vitro [56], antagonism of TRPM7 may prevent tumor metastasis.

TRPs have been divided into seven sub-families: TRPC (canonical), TRPV (vanilloid), TRPM (melastatin), TRPML (mucolipin), TRPP (polycystin), and TRPA (ankyrin transmembrane protein) and TRPN (nomPClike) [15]. In silico analysis of the survival rates of 14 types of tumor expressing 27 types of TRPs showed that high levels of expression of TRPC4, TRPM3, TRPP1, and TRPA1 correlated with significantly better survival rate in patients with clear cell renal cell carcinoma while TRPC4 was found to be closely associated with incidence of head
A

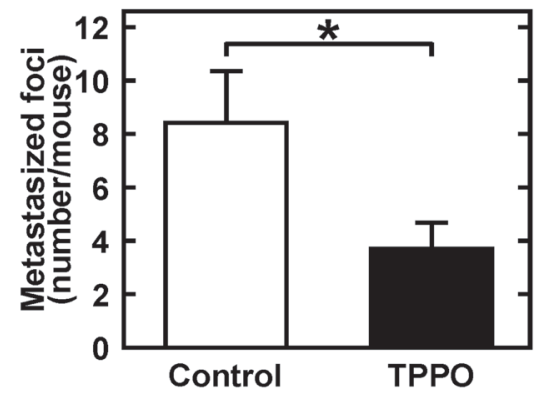

C

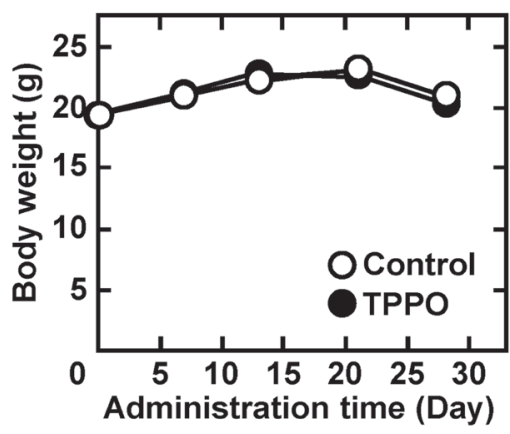

E

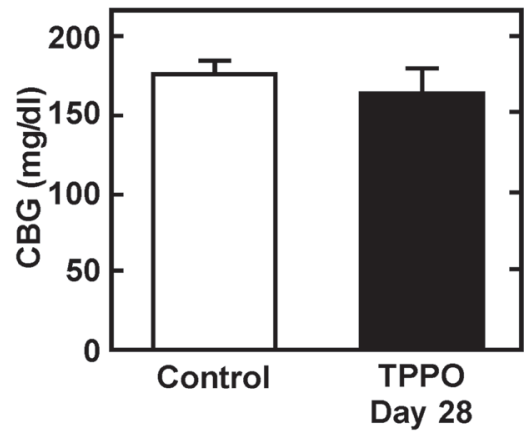

\section{B}

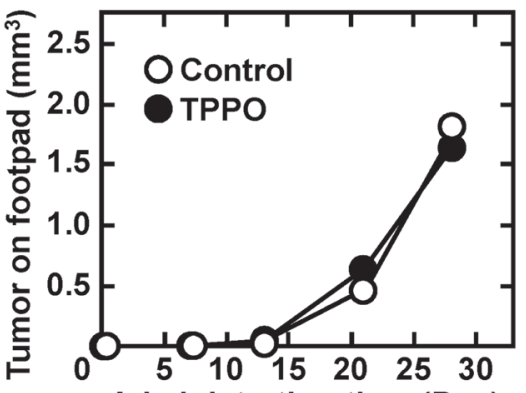

Administration time (Day)
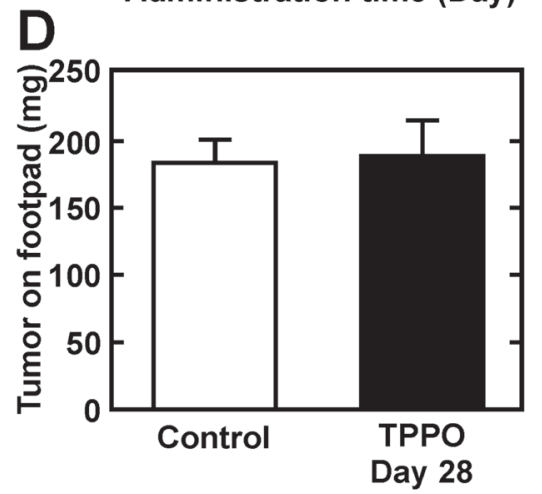

Figure 7: TPPO administration reduces pulmonary metastasis without affecting tumor growth, body weight, or CBG. Cells were injected into the left footpads of mice. Beginning 2 days later, mice were subcutaneously injected with $10 \mathrm{mg} / \mathrm{kg}$ TPPO dissolved in DMSO every other day. Primary tumors were amputated 3 weeks later and treatment with TPPO continued for another 4 weeks. (A) Numbers of pulmonary metastasized foci $(n=17)$. (B) Volumes of primary tumors $(n=17)$. (C) Body weight $(n=17)$. (D) Tumor weight after the amputation of tumor tissue $(n=17)$. (E) CBG concentration $(n=3)$. Data are represented as mean $\pm \mathrm{SE}$. $* P<0.05$. 
A

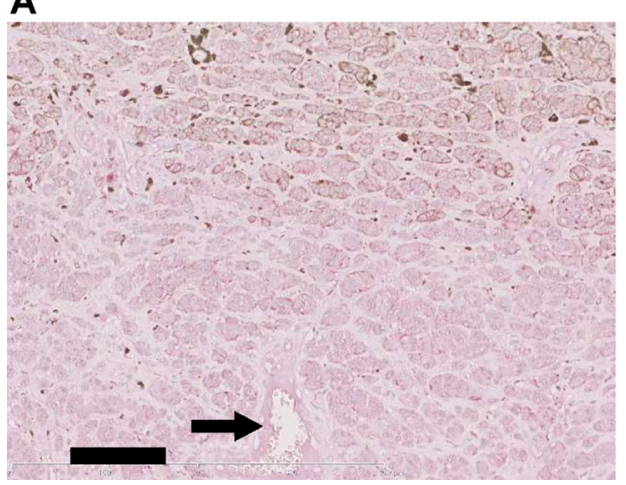

B

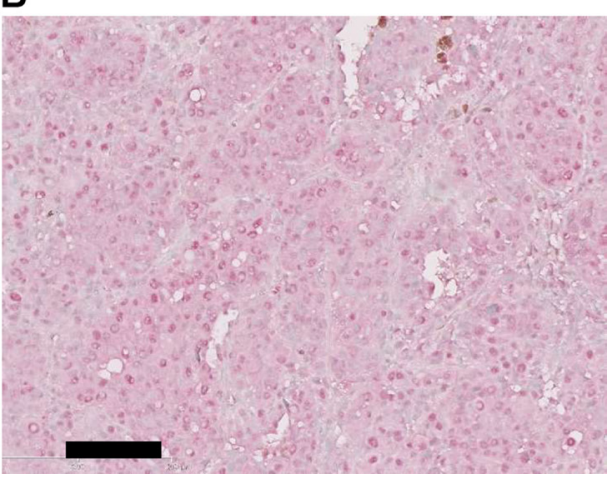

Figure 8: Immunohistochemical analysis of TRPM5 expression in clinical specimens of human melanoma. Representative results of immunohistochemical analysis of TRPM5 expression in primary melanoma (skin) (A) with immunoreactivity evaluated as +++ and secondary melanoma (lung) (B) with immunoreactivity evaluated as +++ . The arrow indicates endothelial cells, defined as the standard for immunoreactivity. Data are summarized in Table 1. Scale bar, $100 \mu \mathrm{m}$.
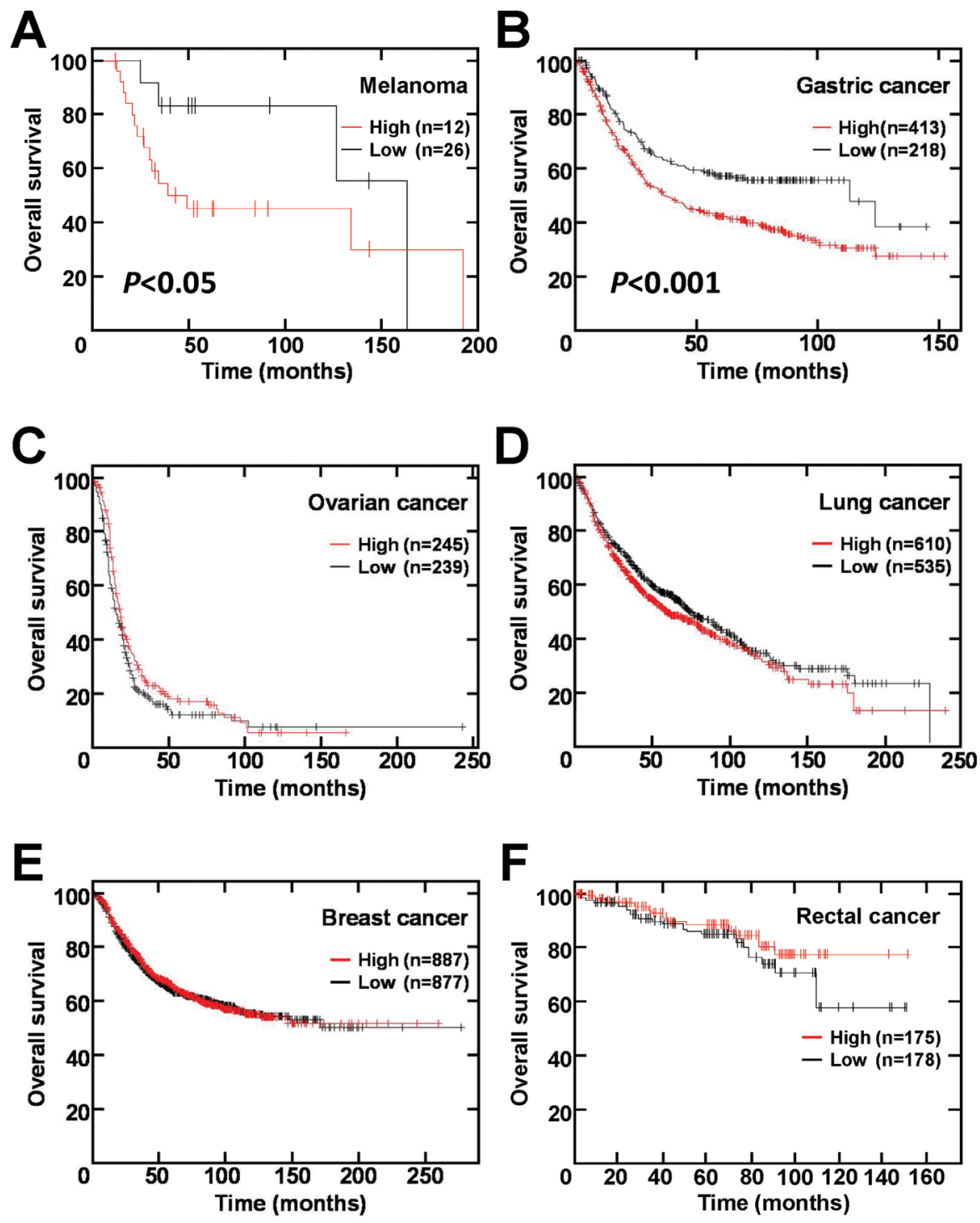

Figure 9: TRPM5 mRNA expression correlates with survival rate of patients with melanoma and gastric cancer. (A) Melanoma. (B) Gastric cancer. (C) Ovarian cancer. (D) Lung cancer. (E) Breast cancer. (F) Rectal cancer. Data were obtained from the Gene Expression Omnibus (GEO; https://www.ncbi.nlm.nih.gov/geo) for melanoma (GSE19234) and rectal cancer (GSE87211) and from the KM-plotter database (http://kmplot.com/analysis/index.php?p=background) for gastric, ovarian, breast, and lung cancer. 
and neck cancer [57]. That study, however, did not analyze TRPM5 expression in melanoma and gastric cancer. The present study found that high levels of TRPM5 expression correlated with significantly shorter overall survival. Unexpectedly, however, immunohistochemical staining for TRPM5 showed no correlation with metastasis. This may be explained by differences between mRNA and the protein half-life of TRPM5. The single nucleotide polymorphism (SNP) database of the National Center for Biotechnology Information of the U.S. National Library of Medicine (http://www.ncbi.nlm.nih.gov/snp/?term=TRPM5) currently includes 10344 SNPs for human TRPM5, suggesting that mutations in TRPM5 may contribute to tumor metastasis. Further studies are needed to clarify the relationship between the polymorphism and the channel activity of TRPM5. It is also necessary to determine which monovalent cation ion permeabilizing through TRPM5 is involved in acidic $\mathrm{pH}_{e}$ signaling for MMP-9 production.

In conclusion, this study is the first to show that TRPM5 is associated with acidic $\mathrm{pH}_{e}$-signaling in $M m p 9$ mRNA expression in B16-BL6 melanoma cells and that pharmacological inhibition of TRPM5 successfully inhibited their spontaneous metastasis. TRPM5 may be a promising target to prevent lung metastasis of some kinds of tumors.

\section{MATERIALS AND METHODS}

\section{Reagents}

Dulbecco's modified Eagle's medium (DMEM), Ham's F12 medium, and High Capacity RNA-to-cDNA kits were purchased from Life Technologies (Grand Island, NY, USA). Rhodamine-phalloidin was from Cytoskeleton, Inc. (Denver, CO, USA). The Dual-luciferase Assay System was from Promega (Madison, WI, USA). TPPO and glucose CII test kit were from Wako (Tokyo, Japan). Isogen total RNA extraction kits were purchased from Nippon Gene (Tokyo, Japan). Ex-Taq polymerase, SYBR Premix Ex Taq II and Xfect ${ }^{\mathrm{TM}}$ transfection reagent were from Takara Bio (Tokyo, Japan). Rhodamine-phalloidin was from Cytoskeleton, Inc. (Denver, CO, USA). Fetal bovine serum (FBS) was from Hyclone (South Logan, UT, USA). The blocking reagent N102 was from NOF (Tokyo, Japan). Immobilon-P PVDF membranes and chemiluminescence reagent were from Merck Millipore (Billerica, MA, USA). Anti-TRPM5 polyclonal antibody was from Alomone Labs (Jerusalem, Israel), and anti-tubulin monoclonal antibody was from Santa Cruz (Dallas, TX, USA). Avidin-conjugated horseradish peroxidase (HRP) was from Bio-Rad (Hercules, CA, USA). Histofine immunohistochemical staining kits were from Nichirei Biosciences (Tokyo, Japan).

\section{Vectors and vector construction}

The plasmid pMEi8FL3, into which the mouse Trpm5 gene had been inserted, was the kind gift of Dr.
Keiko Abe (University of Tokyo, Tokyo, Japan) [58]. The pIRESneo3 vector was purchased from Clontech (Takara Bio). The Trpm5 gene from pMEi8FL3 was subcloned into the EcoRI/NotI site of pIRESneo3.

The NF-кB-driven luciferase reporter construct (pNFkB-Luc) was purchased from Panomics (Fermont, CA, USA). The cytomegalovirus-driven Renilla luciferase reporter vector (pGL4.75[hRluc/CMV]) for normalization of transfection efficiency was from Promega.

\section{Cells and cell culture}

Mouse B16-F1, B16-F10, and B16-BL6 melanoma cells [2-6] were cultured in basal medium, consisting of a 1:1 mixture of DMEM and F12 supplemented with $15 \mathrm{mM}$ HEPES, 4 mM H $\mathrm{PO}_{4} 1.8 \mathrm{~g} / 1 \mathrm{NaHCO}_{3}, 100$ units $/ \mathrm{mL}$ penicillin $\mathrm{G}$, and $0.1 \mathrm{mg} / \mathrm{ml}$ streptomycin sulfate, adjusted to $\mathrm{pH} 7.4$ with $\mathrm{NaOH}$ or $\mathrm{pH} 5.9$ with $\mathrm{HCl}[5,6]$. For serial culture, cells were washed twice with $\mathrm{Ca}^{2+}-\mathrm{Mg}^{2+}$-free Dulbecco's phosphate-buffered saline [PBS(-)], passaged with trypsin/EDTA and cultured in basal medium at $\mathrm{pH}$ 7.4 supplemented with $10 \%$ fetal bovine serum (FBS) at $37^{\circ} \mathrm{C}$ in a humidified atmosphere in a $5 \% \mathrm{CO}_{2}$ incubator.

\section{NF-кB activity}

$\mathrm{NF}-\kappa \mathrm{B}$ activity was determined by transfection of an NF- $\kappa$ B-driven luciferase reporter vector ( $\mathrm{pNF} \kappa \mathrm{B}$ Luc) along with a CMV-driven Renilla luciferase reporter vector (pGL4.75[hRluc/CMV]) as described, with some modifications [4]. Briefly, B16-BL6 cells in 12-well plates were transfected with $2.5 \mu \mathrm{g}$ of a 30:1 mixture of pNFkB-Luc and pGL4.75[hRluc/CMV] per well using Xfect ${ }^{\mathrm{TM}}$. Reporter activity was measured using the dual-luciferase reporter assay system according to the manufacturer's protocol.

\section{Trpm 5 mRNA knock down}

An siRNA oligonucleotide, 5'-GUUGAUGAGG CUCGUGUGAAU-3' (Nippon Gene, Tokyo, Japan) was constructed to knock down Trpm5 mRNA expression in B16-BL6 cells.

\section{RT-PCR and RT-qPCR}

Total RNA was purified with Isogen and reversetranscribed to cDNA using a High-Capacity cDNA Reverse Transcription Kit. The target sequence was amplified by Ex-Taq polymerase and SYBR Premix Ex Taq II in a Thermal Cycler Dice Real Time System (TP870, Takara Bio) using specific primer sequences for Mmp9 (85 bp), 5'-gcc ctg gaa ctc aca cga ca-3' (upstream) and 5'-ttg gaa act cac acg cca gaa-3' (downstream); Mmp2 (125 bp), 5'-aac ggt cgg gaa tac agc ag-3' (upstream) and 5'-gta aac aag gct tca tgg ggg-3' (downstream); Vim (vimentin, 198 bp), 5'-gga cgt ttc caa gec tga cct c-3' (upstream) and 5'-ccg gta ctc gtt tga ctc ctg c-3' 
(downstream); $C d h 2$ (N-cadherin, 132 bp) 5'-gca ttc agc acc cac ctc agt c-3' (upstream) and 5'-tca gca tgg tac ctg cgt gga g-3' (downstream); and Actb (b-actin, 85 bp), 5'cat ccg taa aga cct cta tgc caa c-3' (upstream) and $5^{\prime}$-atg gag cca ccg atc cac a-3' (downstream) [7]. The level of expression of each target gene was normalized relative to the level of $A c t b$ mRNA in the same samples.

\section{Zymography}

MMP-9 activity was determined by zymography as described $[2,3,7]$. Briefly, cells were cultured in a serum-free medium for $24 \mathrm{~h}$. The proteins in the conditioned medium $(\mathrm{CM})$ were precipitated with acetone and separated by electrophoresis in gelatin-containing $7.5 \%$ polyacrylamide gels in the presence of sodium dodecyl sulfate (SDS), without prior heating or reduction. After electrophoresis, the gels were treated with $2.5 \%$ Triton-X100 in Tris-HCl (pH 7.5) / $5 \mathrm{mM} \mathrm{NaCl}$ to remove $\mathrm{SDS}$, incubated in $50 \mathrm{mM}$ Tris- $\mathrm{HCl}(\mathrm{pH} 7.5) / 10 \mathrm{mM} \mathrm{CaCl}_{2}$ for $24 \mathrm{~h}$, and stained with Coomassie Brilliant Blue R-250.

\section{Western blot analysis}

Cells were lysed in RIPA buffer containing inhibitor cocktail as described [5, 59]. Proteins in cell lysate were separated by SDS-acrylamide electrophoresis and transferred onto Immobilon-P polyvinylidene fluoride membranes. The resultant membranes were blocked with TBS-T (20 mM Tris- $\mathrm{HCl}$ [pH 7.5], $150 \mathrm{mM} \mathrm{NaCl}$, and $0.05 \%$ Tween 20 ) containing $20 \%$ blocking regent N102 and treated sequentially with primary antibody, biotinconjugated secondary antibody, and avidin-conjugated horseradish peroxidase. Signals were detected with enhanced chemiluminescence reagents. Anti-a-tubulin antibody was used as a loading control.

\section{Actin stress fiber staining}

Cells were seeded on glass coverslips in DMEM/ F12 (pH 7.4) supplemented with 10\% FBS and incubated overnight. The cells were washed twice with PBS(-) and once with serum-free DMEM/F12 (pH 7.4), incubated with DMEM/F12 (pH 7.4 or 5.9) for $24 \mathrm{~h}$, fixed in $4 \%$ paraformaldehyde/PBS(-) and permeabilized by exposure to $0.2 \%$ Triton X-100/PBS for 2 min [7]. After washing with PBS(-), the cells were incubated with $20 \%$ N102 blocking reagent in PBS(-) and with rhodamine-phalloidin $(1 \mathrm{U} / \mathrm{ml}$ ) for $30 \mathrm{~min}$ at room temperature. Fluorescent signals were detected using a fluorescence microscope (Axio Imager Z1; Carl Zeiss, Oberkochen, Germany).

\section{CBG level}

CBG level was measured using a glucose CII test kit according to the manufacturer's instructions.

\section{Tumor size measurement}

Tumor volumes were calculated using the formula: $1 / 6 \times \pi \times$ Length $(\mathrm{mm}) \times$ Width $(\mathrm{mm}) \times$ Height $(\mathrm{mm})[60]$.

\section{Lung metastasis}

All experimental protocols on animals were performed in accordance with the guidelines of the Ministry of Education, Culture, Sports, Science and Technology and the Ministry of Health, Labor and Welfare of Japan and were approved by the Animal Experimental Committee of Ohu University (Koriyama, Japan). Throughout all experiments, mice were anesthetized with a mixture of medetomidine-hydrochloride, midazolam, and butorphanol-tartrate [61, 62].

B16-BL6 cells were trypsinized, resuspended in serum-containing DMEM/F12 (pH 7.4), and incubated at $37^{\circ} \mathrm{C}$ for $1 \mathrm{~h}$. The cells were washed twice with PBS(-), and resuspended in ice cold PBS(-). In experimental metastasis assays [63], $5 \times 10^{6}$ cells/200 $\mu \mathrm{l} /$ mouse were injected into the tail vein of 7-week-old male C57BL/6 mice (Clea Japan, Tokyo, Japan). Three weeks later, the mice were sacrificed, their lungs were removed and the numbers of metastatic foci counted. Data are representative of two independent experiments.

In spontaneous metastasis assays [64-69], $5 \times 10^{5}$ cells $/ 30 \mu \mathrm{l} /$ mouse were injected into the left footpad of anesthetized 7-week-old male C57BL/6 mice. Beginning 2 days later, TPPO $(10 \mathrm{mg} / \mathrm{kg})$, dissolved in DMSO [27, 70], was subcutaneously administered every other day. After 3 weeks, the mice were anesthetized and their left feet, containing the primary tumors, were amputated. After an additional 4 weeks, the mice were sacrificed, their lungs were removed and the numbers of metastatic foci counted. Data are combined from three independent experiments.

\section{Immunohistochemical staining of TRPM5 in pathological specimens}

Biopsy or surgically resected specimens were collected from 30 patients diagnosed with melanoma from 2002 to 2012 at Fukuoka University Hospital, Fukuoka, Japan. None had received chemotherapy, radiotherapy, or any other adjunct to surgery. Fifteen patients had primary tumors, including 13 in the skin, one in the eyeball, and one in the nasal cavity; and 15 had metastases, including eight in lymph nodes, six in skin, two in the brain, and one each in the lung and liver. Paraffin-embedded samples ( $5 \mu \mathrm{m}$ thick) were pre-treated by incubation in a microwave oven for $10 \mathrm{~min}$ in $10 \mathrm{mM}$ citrate buffer (pH 6.0). The samples were immunohistochemically stained with anti-Trpm5 polyclonal antibody (1:100) using a Histofine immunohistochemical staining kit (Nichirei, Tokyo, Japan). Color was developed with alkaline phosphatase and Fast Red. Specimens were counter 
stained for nuclei with methyl green. The intensity of staining was compared with that in endothelial cells (ECs) and scored as stronger than ECs $(+++)$, equal to ECs $(++)$, weaker than ECs $(+)$, and negative $(-)$.

The clinical study confirmed to Japanese ethical guidelines for clinical and epidemiological studies, based on the Declaration of Helsinki, and was approved (reference \#16-4-10) by the Ethics Committee of Fukuoka University (Fukuoka, Japan). All patients provided written informed consent.

\section{In silico analysis for association of patient outcome with gene expression}

Gene expression data were downloaded from open databases, including the Gene Expression Omnibus (GEO; https:/www.ncbi.nlm.nih.gov/geo) databases GSE19234 for melanoma and GSE87211 for rectal cancer; and the KM-plotter database (http://kmplot.com/analysis/index. php? $\mathrm{p}=$ background) for gastric, ovarian, breast, and lung cancer [71].

\section{Statistical analysis}

Results were expressed as mean $\pm \mathrm{SE}$. Student's $t$-test was used to compare two independent samples. Data of in vitro assays were representative of two or more independent experiments, each of which contained triplicate samples, unless otherwise noted. Immunohistochemistry results were compared by Fisher's exact test, and overall survival was compared by the Wilcoxon test. A $P$ value $<0.05$ was considered statistically significant.

\section{Author contributions}

Conceptualization of this work was done by KM and YK. Investigation was by TM, AS, KK, CM, YM, SO, RH, YN, KN, and YK. Validation was by TM, AS, KK, CM, YM, SO, RH, YN, KN, KM, YK. Visualization was by TM, KK, and YK. Writing of the original draft was by $\mathrm{TM}, \mathrm{AS}, \mathrm{YK}$ and reviewing and editing of the final version were by all of the authors.

\section{ACKNOWLEDGMENTS AND FUNDING}

We sincerely thank Dr. Keiko Abe (University of Tokyo, Tokyo, Japan) and Dr. Yuzo Ninomiya (Kyushu University, Fukuoka, Japan) for mouse Trpm5 geneinserted pMEi8FL3 and Dr. Minoru Wakamori (Tohoku University, Sendai, Japan) for critical suggestions for this study. This work was supported by JSPS KAKENHI Grant Number JP16K11517 (to YK).

\section{CONFLICTS OF INTEREST}

We have no conflicts of interest to disclose.

\section{REFERENCES}

1. Kato Y, Ozawa S, Miyamoto C, Maehata Y, Suzuki A, Maeda T, Baba Y. Acidic extracellular microenvironment and cancer. Cancer Cell Int. 2013; 13:89.

2. Kato Y, Nakayama Y, Umeda M, Miyazaki K. Induction of 103-kDa gelatinase/type IV collagenase by acidic culture conditions in mouse metastatic melanoma cell lines. J Biol Chem. 1992; 267:11424-11430.

3. Kato Y, Ozono S, Shuin T, Miyazaki K. Slow induction of gelatinase B mRNA by acidic culture conditions in mouse metastatic melanoma cells. Cell Biol Int. 1996; 20:375-377.

4. Kato Y, Lambert CA, Colige AC, Mineur P, Noël A, Frankenne F, Foidart JM, Baba M, Hata R, Miyazaki K, Tsukuda M. Acidic extracellular $\mathrm{pH}$ induces matrix metalloproteinase-9 expression in mouse metastatic melanoma cells through the phospholipase D-mitogenactivated protein kinase signaling. J Biol Chem. 2005; 280:10938-10944.

5. Kato Y, Ozawa S, Tsukuda M, Kubota E, Miyazaki K, St-Pierre Y, Hata R. Acidic extracellular $\mathrm{pH}$ increases calcium influx-triggered phospholipase D activity along with acidic sphingomyelinase activation to induce matrix metalloproteinase-9 expression in mouse metastatic melanoma. FEBS J. 2007; 274:3171-3183.

6. Maeda T, Yuzawa S, Suzuki A, Baba Y, Nishimura Y, Kato Y. RhoA mediates the expression of acidic extracellular $\mathrm{pH}$-induced matrix metalloproteinase-9 mRNA through phospholipase D1 in mouse metastatic B16-BL6 melanoma cells. Int J Oncol. 2016; 48:1251-1257.

7. Suzuki A, Maeda T, Baba Y, Shimamura K, Kato Y. Acidic extracellular $\mathrm{pH}$ promotes epithelial mesenchymal transition in Lewis lung carcinoma model. Cancer Cell Int. 2014; 14:129.

8. Peppicelli S, Bianchini F, Torre E, Calorini L. Contribution of acidic melanoma cells undergoing epithelial-tomesenchymal transition to aggressiveness of non-acidic melanoma cells. Clin Exp Metastasis. 2014; 31:423-433.

9. Peppicelli S, Bianchini F, Toti A, Laurenzana A, Fibbi G, Calorini L. Extracellular acidity strengthens mesenchymal stem cells to promote melanoma progression. Cell Cycle. $2015 ; 14: 3088-3100$.

10. Duncan LM, Deeds J, Hunter J, Shao J, Holmgren LM, Woolf EA, Tepper RI, Shyjan AW. Down-regulation of the novel gene melastatin correlates with potential for melanoma metastasis. Cancer Res. 1998; 58:1515-1520.

11. Brożyna AA, Guo H, Yang SE, Cornelius L, Linette G, Murphy M, Sheehan C, Ross J, Slominski A, Carlson JA. TRPM1 (melastatin) expression is an independent predictor of overall survival in clinical AJCC stage I and II melanoma patients. J Cutan Pathol. 2017; 44:328-337.

12. Lazzeri $\mathrm{M}$, Costantini $\mathrm{E}$, Porena $\mathrm{M}$. TRP family proteins in the lower urinary tract: translating basic science into new clinical prospective. Ther Adv Urol. 2009; 1:33-42. 
13. Liu D, Zhang Z, Liman ER. Extracellular acid block and acid-enhanced inactivation of the $\mathrm{Ca}^{2+}$-activated cation channel TRPM5 involve residues in the S3-S4 and S5-S6 extracellular domains. J Biol Chem. 2005; 280:2069120699.

14. Talavera K, Yasumatsu K, Voets $T$, Droogmans G, Shigemura N, Ninomiya Y, Margolskee RF, Nilius B. Heat activation of TRPM5 underlies thermal sensitivity of sweet taste. Nature. 2005; 438:1022-1025.

15. Liberati S, Morelli MB, Nabissi M, Santoni M, Santoni G. Oncogenic and anti-oncogenic effects of transient receptor potential channels. Curr Top Med Chem. 2013; 13:344-366.

16. Sun H, Luo L, Lal B, Ma X, Chen L, Hann CL, Fulton AM, Leahy DJ, Laterra J, Li M. A monoclonal antibody against KCNK9 $\mathrm{K}^{+}$channel extracellular domain inhibits tumour growth and metastasis. Nat Commun. 2016; 7:10339.

17. Martínez R, Stühmer W, Martin S, Schell J, Reichmann A, Rohde V, Pardo L. Analysis of the expression of Kv10.1 potassium channel in patients with brain metastases and glioblastoma multiforme: impact on survival. BMC Cancer. 2015; $15: 839$.

18. Hammadi M, Chopin V, Matifat F, Dhennin-Duthille I, Chasseraud M, Sevestre H, Ouadid-Ahidouch H. Human ether a-gogo $\mathrm{K}^{+}$channel 1 (hEag1) regulates MDA-MB-231 breast cancer cell migration through Orail-dependent calcium entry. J Cell Physiol. 2012; 227:3837-3846.

19. Menéndez ST, Rodrigo JP, Alvarez-Teijeiro S, Villaronga MÁ, Allonca E, Vallina A, Astudillo A, Barros F, Suárez C, García-Pedrero JM. Role of HERG1 potassium channel in both malignant transformation and disease progression in head and neck carcinomas. Mod Pathol. 2012; 25:1069-1078.

20. Bennett ES, Smith BA, Harper JM. Voltage-gated $\mathrm{Na}^{+}$ channels confer invasive properties on human prostate cancer cells. Pflügers Arch Eur J Physiol. 2004; 447:908-914.

21. Fraser SP, Diss JK, Chioni AM, Mycielska ME, Pan H, Yamaci RF, Pani F, Siwy Z, Krasowska M, Grzywna Z, Brackenbury WJ, Theodorou D, Koyutürk M, et al. Voltagegated sodium channel expression and potentiation of human breast cancer metastasis. Clin Cancer Res. 2005; 11:53815389.

22. Busco G, Cardone RA, Greco MR, Bellizzi A, Colella M, Antelmi E, Mancini MT, Dell'Aquila ME, Casavola V, Paradiso A, Reshkin SJ. NHE1 promotes invadopodial ECM proteolysis through acidification of the peri-invadopodial space. FASEB J. 2010; 24:3903-3915.

23. Cardone RA, Greco MR, Zeeberg K, Zaccagnino A, Saccomano M, Bellizzi A, Bruns P, Menga M, Pilarsky C, Schwab A, Alves F, Kalthoff H, Casavola V, et al. A novel NHE1-centered signaling cassette drives epidermal growth factor receptor-dependent pancreatic tumor metastasis and is a target for combination therapy. Neoplasia. 2015; 17:155-166.

24. Oka M, Hitomi T, Okada T, Nakamura Si S, Nagai H, Ohba M, Kuroki T, Kikkawa U, Ichihashi M. Dual regulation of phospholipase D1 by protein kinase $\mathrm{C} \alpha$ in vivo. Biochem Biophys Res Commun. 2002; 294:1109-1113.

25. Deeds J, Cronin F, Duncan LM. Patterns of melastatin mRNA expression in melanocytic tumors. Hum Pathol. 2000; 31:1346-1356.

26. Prawitt D, Enklaar T, Klemm G, Gärtner B, Spangenberg C, Winterpacht A, Higgins M, Pelletier J, Zabel B. Identification and characterization of MTR1, a novel gene with homology to melastatin (MLSN1) and the trp gene family located in the BWS-WT2 critical region on chromosome 11p15.5 and showing allele-specific expression. Hum Mol Genet. 2000; 9:203-216.

27. Palmer RK, Atwal K, Bakaj I, Carlucci-Derbyshire S, Buber MT, Cerne R, Cortés RY, Devantier HR, Jorgensen V, Pawlyk A, Lee SP, Sprous DG, Zhang Z, et al. Triphenylphosphine oxide is a potent and selective inhibitor of the transient receptor potential melastatin-5 ion channel. Assay Drug Dev Technol. 2010; 8:703-713.

28. Brixel LR, Monteilh-Zoller MK, Ingenbrandt CS, Fleig A, Penner R, Enklaar T, Zabel BU, Prawitt D. TRPM5 regulates glucose-stimulated insulin secretion. Pflügers Arch Eur J Physiol. 2010; 460:69-76.

29. Pérez CA, Huang L, Rong M, Kozak JA, Preuss AK, Zhang H, Max M, Margolskee RF. A transient receptor potential channel expressed in taste receptor cells. Nat Neurosci. 2002; 5:1169-1176.

30. Kelley JR, Duggan JM. Gastric cancer epidemiology and risk factors. J Clin Epidemiol. 2003; 56:1-9.

31. Pasic I, Lipton JH. Current approach to the treatment of chronic myeloid leukaemia. Leuk Res. 2017; 55:65-78.

32. Garner AP, Gozgit JM, Anjum R, Vodala S, Schrock A, Zhou T, Serrano C, Eilers G, Zhu M, Ketzer J, Wardwell S, Ning Y, Song Y, et al. Ponatinib inhibits polyclonal drugresistant KIT oncoproteins and shows therapeutic potential in heavily pretreated gastrointestinal stromal tumor (GIST) patients. Clin Cancer Res. 2014; 20:5745-5755.

33. Yang Z, Hackshaw A, Feng Q, Fu X, Zhang Y, Mao C, Tang J. Comparison of gefitinib, erlotinib and afatinib in nonsmall cell lung cancer: A meta-analysis. Int J Cancer. 2017; 140:2805-2819.

34. Jackisch C, Lammers P, Jacobs I. Evolving landscape of human epidermal growth factor receptor 2-positive breast cancer treatment and the future of biosimilars. Breast. 2017; 32:199-216.

35. Kong D, Park EJ, Stephen AG, Calvani M, Cardellina JH, Monks A, Fisher RJ, Shoemaker RH, Melillo G. Echinomycin, a small-molecule inhibitor of hypoxiainducible factor-1 DNA-binding activity. Cancer Res. 2005; 65:9047-9055.

36. Harguindey S, Arranz JL, Polo Orozco JD, Rauch C, Fais S, Cardone RA, Reshkin SJ. Cariporide and other new and powerful NHE1 inhibitors as potentially selective anticancer drugs--an integral molecular/biochemical/metabolic/clinical approach after one hundred years of cancer research. J Transl Med. 2013; 11:282. 
37. Tracey WR, Allen MC, Frazier DE, Fossa AA, Johnson CG, Marala RB, Knight DR, Guzman-Perez A. Zoniporide: a potent and selective inhibitor of the human sodiumhydrogen exchanger isoform 1 (NHE-1). Cardiovasc Drug Rev. 2003; 21:17-32.

38. Fischer H, Seelig A, Beier N, Raddatz P, Seelig J. New drugs for the $\mathrm{Na}^{+} / \mathrm{H}^{+}$exchanger. Influence of $\mathrm{Na}^{+}$ concentration and determination of inhibition constants with a microphysiometer. J Membrane Biol. 1999; 168:39-45.

39. McDonald PC, Winum JY, Supuran CT, Dedhar S. Recent developments in targeting carbonic anhydrase IX for cancer therapeutics. Oncotarget. 2012; 3:84-97. http://doi. org/10.18632/oncotarget.422.

40. Martínez-Zaguilán R, Seftor EA, Seftor RE, Chu YW, Gillies RJ, Hendrix MJ. Acidic $\mathrm{pH}$ enhances the invasive behavior of human melanoma cells. Clin Exp Metastasis. 1996; 14:176-186.

41. Webb SD, Sherratt JA, Fish RG. Alterations in proteolytic activity at low $\mathrm{pH}$ and its association with invasion: a theoretical model. Clin Exp Metastasis. 1999; 17:397-407.

42. Kalliomäki T, Hill RP. Effects of tumour acidification with glucose + MIBG on the spontaneous metastatic potential of two murine cell lines. Br J Cancer. 2004; 90:1842-1849.

43. Rofstad EK, Mathiesen B, Kindem K, Galappathi K. Acidic extracellular $\mathrm{pH}$ promotes experimental metastasis of human melanoma cells in athymic nude mice. Cancer Res. 2006; 66:6699-6707.

44. Lora-Michiels M, Yu D, Sanders L, Poulson JM, Azuma C, Case B, Vujaskovic Z, Thrall DE, Charles HC, Dewhirst MW. Extracellular $\mathrm{pH}$ and P-31 magnetic resonance spectroscopic variables are related to outcome in canine soft tissue sarcomas treated with thermoradiotherapy. Clin Cancer Res. 2006; 12:5733-5740.

45. Al-Husari M, Webb SD. Acid-mediated tumour cell invasion: a discrete modelling approach using the extended Potts model. Clin Exp Metastasis. 2013; 30:793-806.

46. Peppicelli S, Bianchini F, Contena C, Tombaccini D,

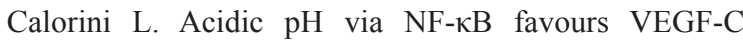
expression in human melanoma cells. Clin Exp Metastasis. 2013; 30:957-967.

47. Sudhan DR, Siemann DW. Cathepsin L inhibition by the small molecule KGP94 suppresses tumor microenvironment enhanced metastasis associated cell functions of prostate and breast cancer cells. Clin Exp Metastasis. 2013; 30:891-902.

48. Justus CR, Dong L, Yang LV. Acidic tumor microenvironment and $\mathrm{pH}$-sensing $\mathrm{G}$ protein-coupled receptors. Front Physiol. 2013; 4:354.

49. Chen B, Liu J, Ho TT, Ding X, Mo YY. ERK-mediated $\mathrm{NF}-\kappa \mathrm{B}$ activation through ASIC1 in response to acidosis. Oncogenesis. 2016; 5:e279.

50. Gupta SC, Singh R, Asters M, Liu J, Zhang X, Pabbidi MR, Watabe K, Mo YY. Regulation of breast tumorigenesis through acid sensors. Oncogene. 2016; 35:4102-4111.
51. Gonzales CB, Kirma NB, De La Chapa JJ, Chen R, Henry MA, Luo S, Hargreaves KM. Vanilloids induce oral cancer apoptosis independent of TRPV1. Oral Oncol. 2014; 50:437-447.

52. Szallasi A, Sheta M. Targeting TRPV1 for pain relief: limits, losers and laurels. Expert Opin Inv Drug. 2012; 21:1351-1369.

53. Fischer MJ, Reeh PW, Sauer SK. Proton-induced calcitonin gene-related peptide release from rat sciatic nerve axons, in vitro, involving TRPV1. Eur J Neurosci. 2003; 18:803-810.

54. Rukwied R, Chizh BA, Lorenz U, Obreja O, Margarit S, Schley M, Schmelz M. Potentiation of nociceptive responses to low $\mathrm{pH}$ injections in humans by prostaglandin $\mathrm{E}_{2}$. J Pain. 2007; 8:443-451.

55. Wong BJ, Fieger SM. Transient receptor potential vanilloid type 1 channels contribute to reflex cutaneous vasodilation in humans. J Appl Physiol. 2012; 112:2037-2042.

56. Wong R, Turlova E, Feng ZP, Rutka JT, Sun HS. Activation of TRPM7 by naltriben enhances migration and invasion of glioblastoma cells. Oncotarget. 2017; 8:11239-11248. http://doi.org/10.18632/oncotarget.14496.

57. Park YR, Chun JN, So I, Kim HJ, Baek S, Jeon JH, Shin SY. Data-driven analysis of TRP channels in cancer: linking variation in gene expression to clinical significance. Cancer Genom Proteom. 2016; 13:83-90.

58. Oike H, Wakamori M, Mori Y, Nakanishi H, Taguchi R, Misaka T, Matsumoto I, Abe K. Arachidonic acid can function as a signaling modulator by activating the TRPM5 cation channel in taste receptor cells. Biochim Biophys Acta. 2006; 1761:1078-1084.

59. Baba Y, Fujii M, Maeda T, Suzuki A, Yuzawa S, Kato Y. Deguelin induces apoptosis by targeting both EGFR-Akt and IGF1R-Akt pathways in head and neck squamous cell cancer cell lines. BioMed Res Int. 2015; 2015:657179.

60. McIntyre A, Patiar S, Wigfield S, Li JL, Ledaki I, Turley H, Leek R, Snell C, Gatter K, Sly WS, Vaughan-Jones RD, Swietach P, Harris AL. Carbonic anhydrase IX promotes tumor growth and necrosis in vivo and inhibition enhances anti-VEGF therapy. Clin Cancer Res. 2012; 18:3100-3111.

61. Kawai S, Takagi Y, Kaneko S, Kurosawa T. Effect of three types of mixed anesthetic agents alternate to ketamine in mice. Exp Anim. 2011; 60:481-487.

62. Kirihara Y, Takechi M, Kurosaki K, Kobayashi Y, Kurosawa T. Anesthetic effects of a mixture of medetomidine, midazolam and butorphanol in two strains of mice. Exp Anim. 2013; 62:173-180.

63. Hata R, Izukuri K, Kato Y, Sasaki S, Mukaida N, Maehata Y, Miyamoto C, Akasaka T, Yang X, Nagashima Y, Takeda K, Kiyono T, Taniguchi M. Suppressed rate of carcinogenesis and decreases in tumour volume and lung metastasis in CXCL14/BRAK transgenic mice. Sci Rep. 2015; 5:9083.

64. Ohba Y, Kanao Y, Morita N, Fujii E, Hohrai M, Takatsuji M, Hirose H, Miura D, Watari A, Yutsudo M, Zhao H, Yabuta N, Ito A, et al. Oleamide derivatives suppress the spontaneous metastasis by inhibiting connexin 26. Int J Cancer. 2007; 121:47-54. 
65. Talmadge JE. (2010). Models of metastasis in drug discovery. In: Proetzel G, Wiles MV, eds. Mouse Models for Drug Discovery: Methods and Protocols. (New York: Humana Press), pp. 215-233.

66. Ueno Y, Sakurai H, Tsunoda S, Choo MK, Matsuo M, Koizumi K, Saiki I. Heregulin-induced activation of ErbB3 by EGFR tyrosine kinase activity promotes tumor growth and metastasis in melanoma cells. Int J Cancer. 2008; 123:340-347.

67. Box GM, Eccles SA. (2011). Simple experimental and spontaneous metastasis assays in mice. In: Wells CM, Parsons M, eds. Cell migration: developmental methods and protocols. (New York: Humana Press), pp. 311-329.

68. Zhang H, Liu L, Yu D, Kandimalla ER, Sun HB, Agrawal $\mathrm{S}$, Guha C. An in situ autologous tumor vaccination with combined radiation therapy and TLR9 agonist therapy. PLoS One. 2012; 7:e38111.
69. Porporato PE, Payen VL, Pérez-Escuredo J, De Saedeleer CJ, Danhier P, Copetti T, Dhup S, Tardy M, Vazeille T, Bouzin C, Feron O, Michiels C, Gallez B, et al. A mitochondrial switch promotes tumor metastasis. Cell Rep. 2014; 8:754-766.

70. Ren Z, Rhyu MR, Phan TH, Mummalaneni S, Murthy KS, Grider JR, DeSimone JA, Lyall V. TRPM5-dependent amiloride- and benzamil-insensitive $\mathrm{NaCl}$ chorda tympani taste nerve response. Am J Physiol Gastrointest Liver Physiol. 2013; 305:G106-117.

71. Szász AM, Lánczky A, Nagy Á, Förster S, Hark K, Green JE, Boussioutas A, Busuttil R, Szabó A, Győrffy B. Cross-validation of survival associated biomarkers in gastric cancer using transcriptomic data of 1,065 patients. Oncotarget. 2016; 7:49322-49333. http://doi.org/10.18632/ oncotarget.10337. 